\title{
The qualitative spray analysis of liquid fuel in high-pressure piezoelectric injection system
}

\begin{abstract}
The paper presents the methodology and tests results of the influence of the fuel injection pressure and combustion chamber back pressure on the changes of the fuel spray geometrical parameters injection uniformity and its quality during the injection. While evaluating the geometrical fuel spray parameters the spray penetration, speed of propagation were taken into account and while evaluating the quality of the fuel atomization the outflow of the fuel from the injector were considered. The tests reported here were performed for one value of the air back pressure at the various injection pressures. The fuel doses were changed by modifying the duration of the injection. A significant influence of theses parameters on the values of the operating indexes of the injection and atomization processes has been noted.
\end{abstract}

Keywords: fuel injection, fuel distribution, optical investigation

\section{Jakościowa analiza rozpylenia paliwa ciekłego w wysokociśnieniowych piezoelektrycznych układach wtryskowych}

\begin{abstract}
Artykut przedstawia analize rozpylenia paliwa z wtryskiwaczy piezoelektrycznych pracujacych $w$ układach wtrysku wysokociśnieniowego stosowanego $w$ silnikach o zapłonie iskrowym i samoczynnym. Przedstawiono w nim metodyke $i$ wyniki badań wpływu ciśnienia wtrysku paliwa oraz przeciwciśnienia w komorze stałociśnieniowej na zmiany parametrów geometrycznych strugi w czasie trwania wtrysku, równomierność wtrysku oraz jakość rozpylenia paliwa. W ocenie parametrów geometrycznych strugi brano pod uwagę zasięg strugi, prędkość rozprzestrzeniania się czoła strugi paliwa, a przy ocenie jakości rozpylenia paliwa - sposób wyptywu paliwa z wtryskiwacza. Badania wykonano dla kilku wartości przeciwciśnienia powietrza przy różnych ciśnieniach wtrysku. Wielkość dawki różnicowano przez zmianę czasu trwania wtrysku. Stwierdzono istotny wpływ tych parametrów na wartości wskaźników operacyjnych procesu wtrysku i rozpylenia paliwa.
\end{abstract}

Słowa kluczowe: wtrysk paliwa, rozktad paliwa, badania optyczne

\section{Introduction}

The high pressure injection common for CI (compressed ignition) engines has even more dominant role in the preparation of the mixture in SI (spark ignition) engines [12]. The multipulse injection is being applied in the SI engines as well. Due to pressure values of the injected fuel - gasoline (at present approx. $20 \mathrm{MPa}$ ), the injection duration is similar to the injection duration of diesel oil.

Similarly to CI engines, piezoelectric fuel injectors are beginning to dominate in SI engines (Fig. 1a), in which, however, the injected fuel spray has a different character and different geometrical indexes and fuel flows out of the injector along the spray cone.

Electromagnetic injectors were used in the first and second generation common rail (CR) systems. The reason for their withdrawal in favor of the piezoelectric injectors is the lack of the possibility of obtaining small time intervals between the subsequent fuel doses in a single engine operating cycle. Hence, the number of injections was limited to three or four in a single cycle. Piezoelectric injectors are fitted in third and fourth generation CR systems. Their main advantage is the possibility of a multiple division of the fuel dose into doses of relatively short durations. The build of the piezoelectric injector by Bosch has been shown in Fig. 1 b.

\section{Wstęp}

Wtrysk wysokociśnieniowy rozpowszechniony w silnikach o zapłonie samoczynnym coraz częściej zaczyna odgrywać dominującą rolę w przygotowaniu mieszanki także w silniku o zapłonie iskrowym [12]; wykorzystywany jest tu również wtrysk wielofazowy. Ze względu na wartości ciśnienia wtryskiwanego paliwa - benzyny (obecnie do okoto $20 \mathrm{MPa}$ ), czasy wtrysku zbliżone są do czasów wtrysku oleju napędowego.

Podobnie jak w silnikach o zapłonie samoczynnym, także w silnikach o zapłonie iskrowym zaczynają dominować wtryskiwacze piezoelektryczne (rys. 1a), w których jednak wtryskiwana struga paliwa ma inny charakter i inne wskaźniki geometryczne.

Wtryskiwacze elektromagnetyczne były wykorzystywane w układach common rail (CR) pierwszej i drugiej generacji. Powodem ich zastępowania przez wtryskiwacze piezokwarcowe jest brak możliwości uzyskania małych odstępów czasu między kolejnymi dawkami wtryskiwanego paliwa podczas jednego cyklu pracy silnika. $Z$ tego powodu ograniczano liczbę wtryskiwanych dawek do trzech lub czterech. Wtryskiwacze piezoelektryczne są wykorzystywane w układach CR trzeciej i czwartej generacji. Ich główną zaletą jest możliwość uzyskania wielokrotnego podziału dawki 

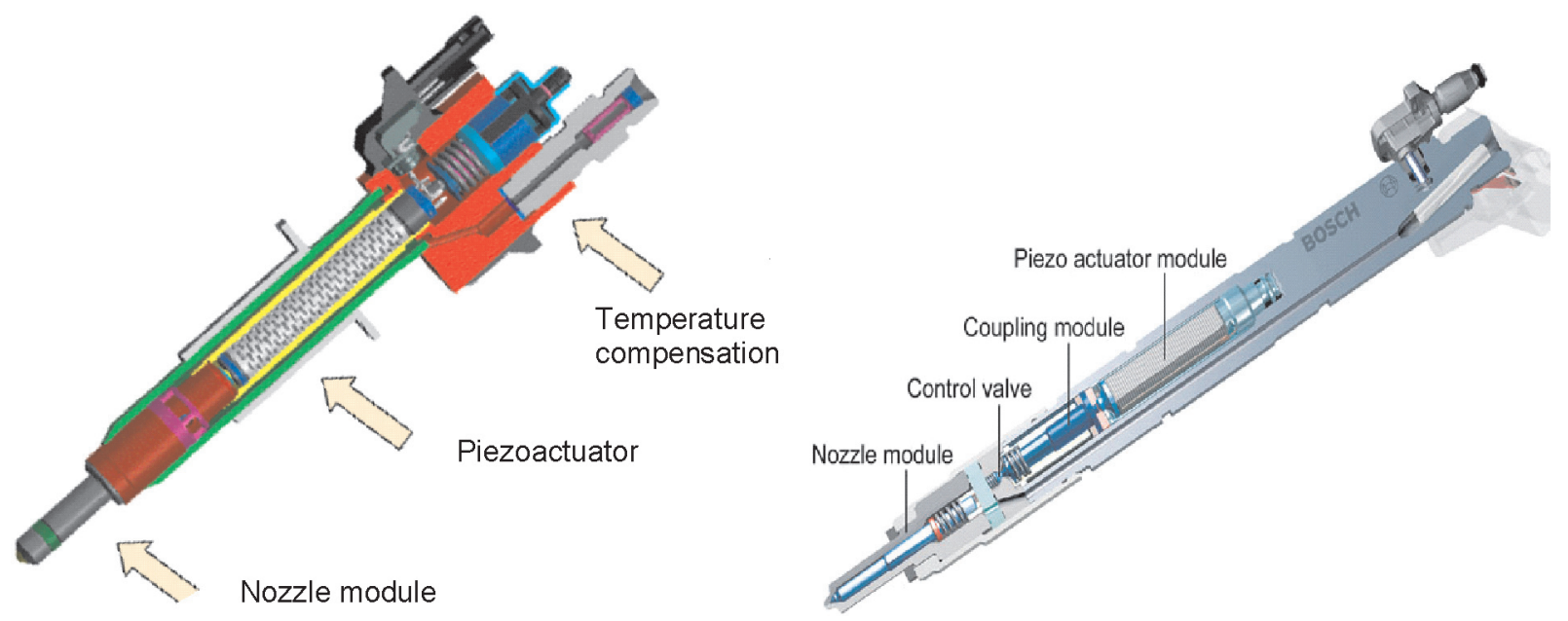

Fig. 1. Piezoelectric injector: a) SI injector, b) CI injector Rys. 1. Wtryskiwacz piezoelektryczny: a) silnika ZI, b) silnika ZS

\section{Test stand}

At this stage of the investigation the authors investigated the influence of the fuel injection pressure and fuel temperature on the fuel spray shape, atomization and spray front displacement.

The tests (for CI injector) were performed for a multi hole injector - yet, each time, all the injector holes (seven) were observed and analyzed (Fig. 2, 3).

The controlled injector was placed in a closed chamber with the adjustable backpressure in the range 0-4.5 MPa.

The test-stand (for SI injector) incorporated the highpressure gasoline injection system (outwardly opening injector) equipped with the high-pressure and feeding pumps. The piezoelectrically controlled gasoline injector was placed in the closed chamber (tab. 1) with the controlled back-pressure. Positioning of the injector allows recording of images of injection course from the side (for the analysis of axial fuel

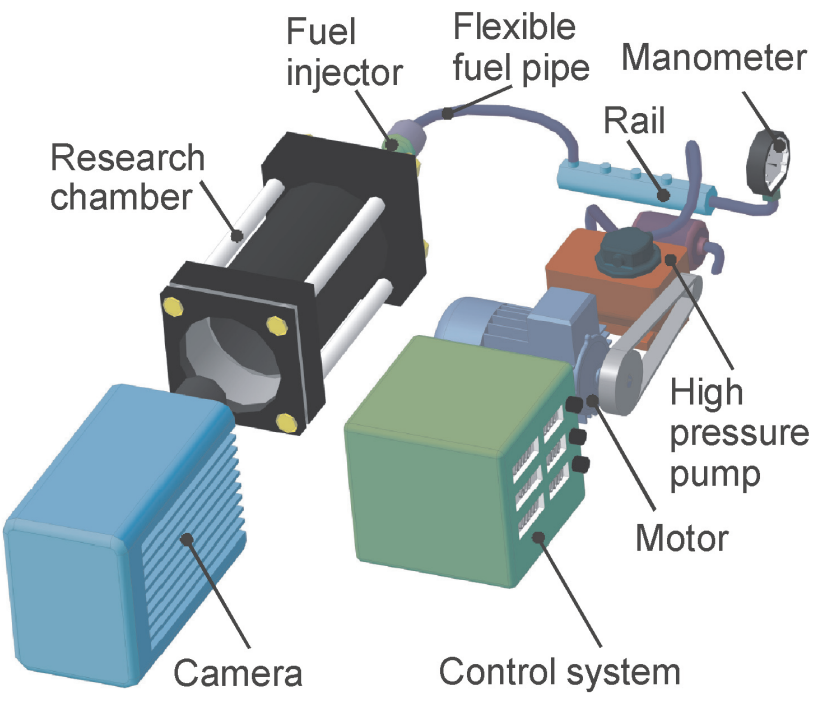

Fig. 2. Test-stand for research on fuel spray evaluation Rys. 2. Stanowisko badawcze do badań rozpylenia paliwa paliwa ze względnie krótkimi czasami między kolejnymi dawkami paliwa. Budowa wtryskiwacza piezokwarcowego firmy Bosch została przedstawiona na rys. $1 \mathrm{~b}$.

\section{Aparatura badawcza}

Prezentowany etap prowadzonych badań polegał na ocenie wpływu ciśnienia wtrysku i temperatury paliwa na wskaźniki kształtu strugi paliwa, jego rozpylenia oraz zasięgu strugi.

Badania strugi paliwa przeprowadzono dla wtryskiwacza wielootworkowego silnika ZS; analizowano jednocześnie wszystkie strugi paliwa (siedem) - rys. 2, 3 .

Wtryskiwacz umieszczono w komorze stałociśnieniowej o stałej objętości, w której istnieje możliwość regulacji ciśnienia powietrza w zakresie 0-4.5 MPa.

Stanowisko badawcze (wtryskiwacz silnika ZI) zbudowane jest $\mathrm{z}$ układu wtrysku wysokociśnieniowego benzyny wraz z pompami: wysokociśnieniową i zasilającą.

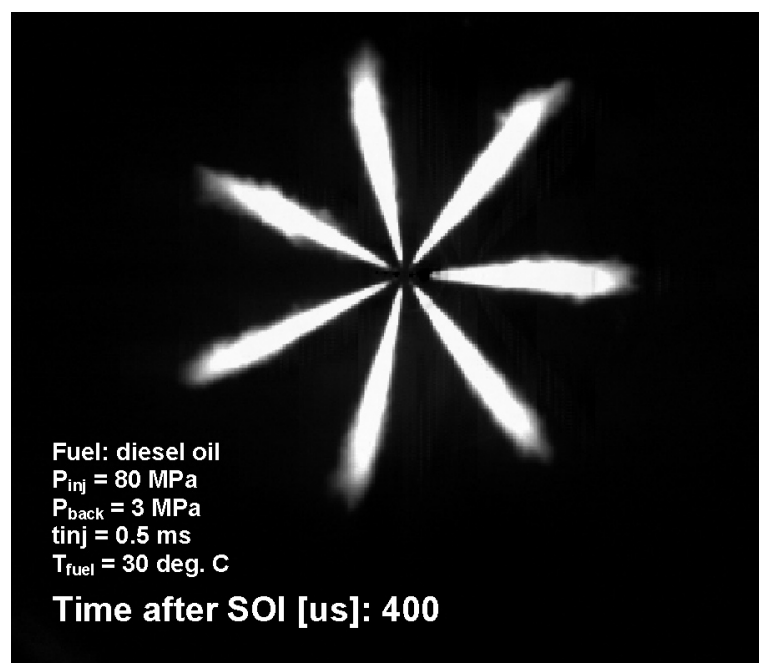

Fig. 3. Example of the recorded observations of fuel spray Rys. 3. Przykład obserwacji zarejestrowanej strugi paliwa 
Table 1. Technical data of the test chamber

Tablica 2. Dane techniczne komory badawczej

\begin{tabular}{|c|c|c|c|}
\hline \multirow[t]{4}{*}{ Chamber/komora } & Outer diameter/średnica zewnętrzna & Material/materiat $(\Phi \times \mathrm{H})$ & Steel $/$ stal $(110 \mathrm{~mm} \times 400 \mathrm{~mm})$ \\
\hline & \multirow[t]{2}{*}{ Inner core/średnica wewnętrzna } & Material/materiał $(\Phi \times \mathrm{H})$ & Steel/stal $(90 \mathrm{~mm} \times 350 \mathrm{~mm})$ \\
\hline & & Volume/objętość & $2200 \mathrm{~cm}^{3}$ \\
\hline & $\begin{array}{c}\text { Accessible pressure/regulowane } \\
\text { ciśnienie }\end{array}$ & $0-4.5 \mathrm{MPa}$ & \\
\hline \multirow[t]{2}{*}{ Heater/podgrzewanie } & Air/powietrze & $\begin{array}{c}\text { External heating/zewnętrzny } \\
\text { uktad podgrzewania }\end{array}$ & $20-100^{\circ} \mathrm{C}$ \\
\hline & Fuel/paliwo & $\begin{array}{l}\text { Heating injector/podgrzewa- } \\
\text { nie wtryskiwacza }\end{array}$ & $20-200^{\circ} \mathrm{C}$ \\
\hline Windows/dostep optyczny & Material/thickness/materiat/grubość & \multicolumn{2}{|c|}{ Quartz Glass/30 mm/okno kwarcowe } \\
\hline \multirow[t]{4}{*}{ Injector/wtryskiwacz } & \multirow[t]{3}{*}{ Injection/wtrysk } & Pressure/ciśnienie & 5-30 MPa \\
\hline & & Duration/czas wtrysku & $0.2-5 \mathrm{~ms}$ \\
\hline & & Fuel/paliwo & $\begin{array}{c}\text { Ethanol, Gasoline/B100, Diesel/eta- } \\
\text { nol/benzyna/B100, olej napędowy }\end{array}$ \\
\hline & Injector type/typ wtryskiwacza & $\begin{array}{l}\mathrm{SI} / \mathrm{CI} \text { piezo/ZI/ZS piezoelek- } \\
\text { tryczne }\end{array}$ & Multi-hole, Outward-opening, $90^{\circ}$ \\
\hline Light/oświetlenie & Type/typ & $\begin{array}{c}2 \times \text { Halogen Lamp/oświelte- } \\
\text { nie halogenowe }\end{array}$ & $24 \mathrm{~V} ; 250 \mathrm{~W}$, angle $30 \mathrm{o}$ \\
\hline
\end{tabular}

spray penetration) and from the bottom of the spray (for the observations of radial spray penetration).

The location of the camera, the sources of light and the fuel sprays under analysis have been shown in Fig. 4.

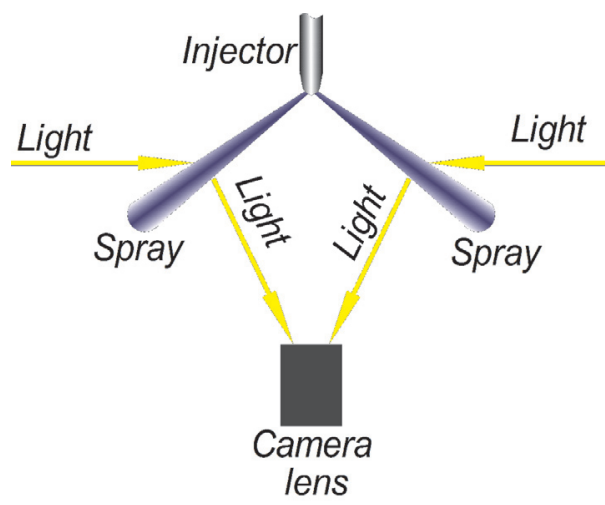

Fig. 4. Location of the camera and lighting against the fuel spray (CI injector)

Fig. 4. Sposób usytuowania kamery i oświetlenia w stosunku do strugi paliwa (wtryskiwacz ZS)

Such a setting of the camera and the lighting (perpendicular to each other) results in lower illumination of the fuel spray, which, again, results in lower illumination intensity in its core. The images with a less evaporated fuel in the core (containing large droplets) should have a higher luminance. Yet the fuel at the rim of the cone should also have a little luminance (due to a small light reflection from the evaporated fuel).

\section{Diesel Spray Atomization in Common-Rail Piezoinjector System}

\subsection{Overview of the literature}

The prospects of depleting fossil fuels as well as the environmental concerns have resulted in a growing interest
Piezoelektryczny wtryskiwacz benzyny znajduje się w komorze pomiarowej (tab. 1), w której można zmieniać ciśnienie powietrza. Usytuowanie wtryskiwacza pozwala na jego równoległe (obserwacja kołowości strugi paliwa) i prostopadłe filmowanie (obserwacja rzutu stożka rozpylenia).

Wzajemne położenie kamery, źródeł światła oraz analizowanych strug paliwa przedstawiono na rys. 4 .

Takie ustawienie kamery i oświetlenia (wzajemnie prostopadłe) powoduje, że struga bogata w paliwo zostaje prześwietlona $\mathrm{w}$ mniejszym stopniu, co skutkuje mniejszą intensywnością świecenia $\mathrm{w}$ jej rdzeniu. Zdjęcia z bardziej odparowanym paliwem w rdzeniu (zawierającym również duże krople) powinny posiadać mniejszą luminancję (struga mniej przezroczysta). Jednakże odparowane paliwo na brzegu stożka powinno mieć również niewielką luminancję (ze względu na niewielkie odbicie światła od odparowanej części paliwa).

\section{Rozpylenie paliwa w piezoelektrycznym układzie wtrysku oleju napędowego}

\subsection{Przegląd literatury}

Perspektywy wyczerpania się zasobów paliw kopalnych oraz obawy o stan środowiska naturalnego człowieka znacznie zwiększyły zainteresowanie alternatywnymi źródłami energii do napędu środków transportu. Doprowadziło to do dużego zainteresowania paliwami alternatywnymi w tym paliwem B100 (ester metylowy) stanowiące samoistne paliwo silnikowe. Ze względu na dużą popularność paliwa B100 zostało ono poddane analizie wpływu temperatury na jego rozpylenie.

Pierwsze dokumenty dotyczące paliwa B100 wprowadzone w Niemczech w 1994 roku zostały zawarte w PreNorm DIN V 51606. Obowiązujące standardy dotyczące paliwa B100 w Unii Europejskiej zawarto w normie EN 14214 (data wprowadzenia - 2003 rok) [3]. 
in alternative energy sources in transportation. This led to a substantially high interest in the B100 fuel - a methyl ester being a standalone engine fuel. Due to a high popularity of the B100 fuel it was subjected to the analysis of the influence of the temperature on its atomization.

The first EU B100 standard was introduced in 1994 in Germany as Pre-Norm DIN V 51606. The first (and still valid) EU B100 standard, EN 14214, was introduced in 2003 [3].

The first provisional standard for B100 in US was approved in 1999, and an official one was adopted in 2002 as ASTM D6751-02 [1]

The varieties of B100 sold in Europe and the U.S. are characterized by slightly different properties. The authors, in paper [6], state that the EU specification for B100 is considered to be more stringent than the ASTM, but the quality of B100 is very similar comparing the samples from the U.S. and the EU.

The use of biofuels in combustion engines has been a subject of a multitude of scientific papers. The investigations on the combustion of B100 [8, 11] and its atomization [14] have been carried out, yet the authors did not analyze the influence of the temperature of the fuel on the quality of its atomization. The authors [13] used pure B100 as the alternative fuel for combustion as well as mixtures of fuels.

The results of the tests presented in [15] are related to the stroboscopic tests of the B100 atomization as well as other biodiesel (diesel oil mixtures). In these tests several consequent injections are used in order to obtain the testing material. Such tests are applicable if we assume repeatability of the operation of the injection system.

$\mathrm{B} 100$ is used in the road tests of vehicles fitted with common rail system compliant with the Euro 3 [19] and Euro 5 [7] standards fitted with electromagnetic injectors. There are no tests of the B100 fuel related to the system fitted with piezoelectric injectors. Hence, the authors used the piezoelectric injectors on purpose (they were also the subject of the analysis of diesel oil injection [17]) because the scientific papers did not provide sufficient research information on this subject.

The additional purpose of the presented here investigation is the analysis of the influence of the temperature of B100 on the quality of its atomization: distribution of the fuel in the spray resulting from its heating (Fig. 5).

\subsection{Spread between the fuel sprays}

In order to obtain a full description of the fuel injection, tests determining the differences in the penetration of the fuel spray flowing out of all seven holes of the injector were performed. The results of these tests have been shown in Fig. 6.

Figure 6 shows significant differences in the penetration of fuel sprays and the area occupied by these fuel sprays. The spreads in the fuel spray penetration grow in time from the onset of the injection. Until $500 \mu$ s after the onset of the fuel injection the spread amounts to approximately $15 \%$ counting from the average value (marked with black bold). Further growth in the fuel atomization results in higher
Przepisy amerykańskie dotyczące paliwa B100 pojawiły się w 1999 roku, natomiast oficjalne potwierdzenie znalazły w normie ASTM D6751-02 z 2002 r. [1].

Paliwo B100 sprzedawane w Europie i USA cechuje się nieco odmiennymi właściwościami. Autorzy, w artykule [6] stwierdzają, że europejska specyfikacja paliwa B100 jest bardziej restrykcyjna niż amerykańska, określona przez ASME, jednak jakość obu testowanych typów paliw jest podobna.

Zastosowanie biopaliw w silnikach spalinowych było już elementem wielu artykułów. Podejmowano badania spalania B100 [8, 11] oraz jego rozpylenia [14], jednak autorzy nie rozpatrywali wpływu temperatury paliwa na jakość rozpylenia. Autorzy [13] jako paliwa alternatywne do spalania wykorzystali czysty B100 oraz mieszaniny paliw.

Wyniki badań przedstawione w [15] dotyczą badań stroboskopowych rozpylenia B100 oraz innych mieszanin biodiesla z olejem napędowym. W badaniach tych wykorzystuje się kilka kolejnych wtrysków w celu uzyskania materiału badawczego. Badania takie są celowe jeśli przyjmuje się powtarzalność działania aparatury wtryskowej.

Biopaliwo typu B100 wykorzystywane jest w badaniach drogowych pojazdów zasilanych układami common rail spełniającymi normy emisji Euro 3 [19] and Euro 5 [7] wyposażonymi we wtryskiwacze elektromagnetyczne. Brak jest natomiast badań paliwa B100 w układach wyposażonych we wtryskiwacze piezoelektryczne. Autorzy tego artykułu wykorzystali celowo wtryskiwacze piezoelektryczne (które były również przedmiotem analiz podczas wtrysku oleju napędowego [17]), ze względu na niedostateczne informacje badawcze w literaturze naukowej.

Dodatkowym celem przedstawianych tutaj badań była analiza wpływu temperatury paliwa B100 na jakość rozpylenia paliwa: zasięg wtrysku, obszar zajmowany przez strugę paliwa, prędkości strugi paliwa oraz rozkład paliwa w strudze w wyniku jej podgrzewania (rys. 5).

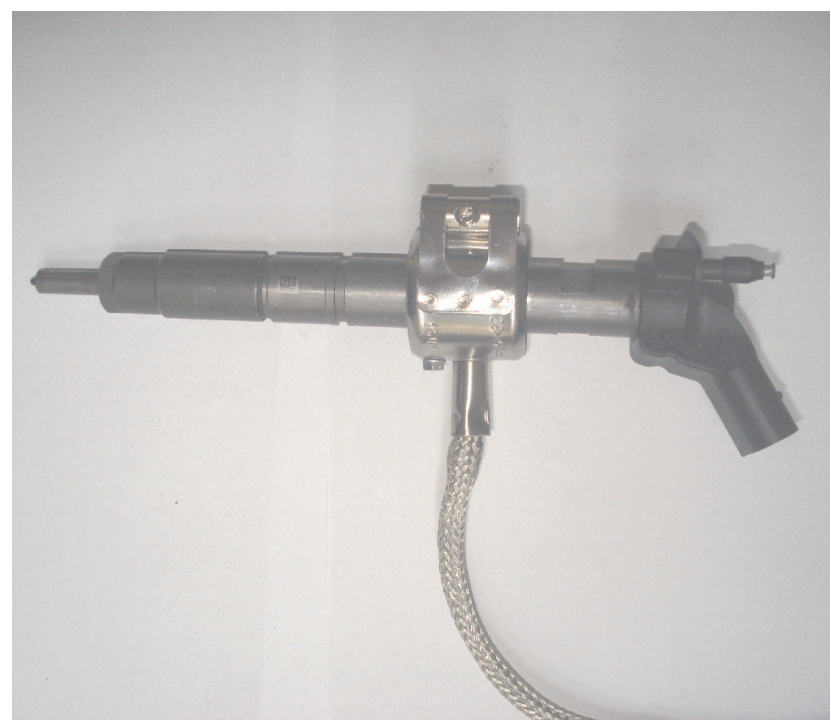

Fig. 5. Injector with heating element (CI injector)

Rys. 5. Podgrzewanie wtryskiwacza paliwa (wtryskiwacz ZS) 
spreads (approximately 30\% in the time of 1.5-2.0 ms after the onset of the injection). The area occupied by the fuel spray changes slightly in the initial phase of the injection. During further fuel atomization the spreads are constant and amount to approximately 15\% (two extreme cases excluded) irrespective of the atomization time. For this reason, for further analysis of the fuel spray penetration and fuel spray area averaged values (taken out of seven fuel sprays) of the fuel spray penetration were used.

\subsection{The analysis of the fuel spray penetration, its area and velocity}

The analysis of the fuel spray area and velocity was performed separately for each tested fuel injection time $\left(\mathrm{t}_{\mathrm{inj} 1}\right.$ $=0.3 \mathrm{~ms}$ and $\left.\mathrm{t}_{\mathrm{inj} 2}=0.5 \mathrm{~ms}\right)-$ Fig. 7 .

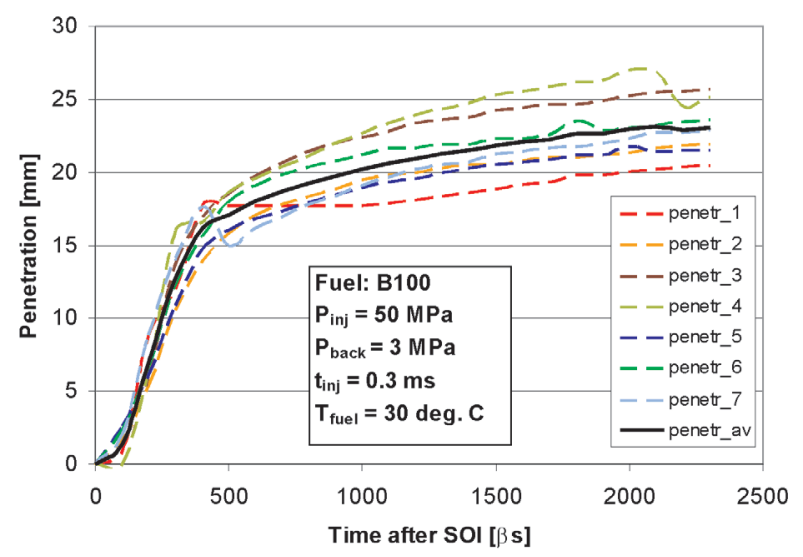

Fig. 6. The analysis of the fuel atomization level - fuel spray penetration Rys. 6. Analiza rozpylenia paliwa-zasięgi poszczególnych strug paliwa

In the case of an injection with the pressure of $50 \mathrm{MPa}$ the speed of spray front propagation can be assessed at 60 $\mathrm{m} / \mathrm{s}$ and the maximum value is reached after approximately 200-450 $\mu$ s after the onset of the injection. In the mid phase of the injection, the speed of propagation was bigger for the injection pressure of $80 \mathrm{MPa}$ as compared to an injection pressure of $50 \mathrm{MPa}$ by approximately $20-25 \mathrm{~m} / \mathrm{s}$. In the case of an injection with the pressure of $80 \mathrm{MPa}$ the speed of spray propagation was approximately $80-85 \mathrm{~m} / \mathrm{s}$. In both cases the courses of this speed almost overlap in the initial and final phases of the injection.

The penetration of the spray front for both injection pressure in the initial phase of the injection is similar and in the final injection phase differs by $30 \%$. For the pressure of $80 \mathrm{MPa}$ and time $500 \mu$ s the penetration of both sprays (similarly to the pressure of $50 \mathrm{MPa}$ ) in the initial phase of the injection is identical and the maximum difference (in the injection time between $1000-1200 \mu \mathrm{s}$ ) is $40 \%$.

\subsection{The analysis of the fuel distribution in the fuel spray axis}

The distribution of the fuel in the fuel spray has been estimated on the basis of the distribution of luminance of the light reflected from the fuel droplets in the fuel spray axis. The values of this luminance are within the range of 0 (no

\subsection{Rozrzuty między wtryskiwanymi strugami}

W celu uzyskania pełnego opisu wtrysku paliwa wykonano badania określenia różnic w zasięgu strugi wypływającej przez wszystkie siedem otworków wtryskiwacza. Wyniki tych badań przedstawiono na rys. 6 .

$Z$ rys. 6 wynikają znaczne różnice w zasięgu strugi oraz obszarze przez nie zajmowanym. Rozrzuty zasięgu strug zwiększają się wraz z upływem czasu od początku wtrysku. Do czasu $500 \mu$ s po rozpoczęciu wtrysku rozrzuty wynoszą około 15\% od wartości średniej (zaznaczonej kolorem czarnym pogrubionym). Dalszy wzrost rozpylenia skutkuje większymi rozrzutami (około 30\% w czasie 1,5-2,0 ms po rozpoczęciu wtrysku). Obszar zajmowany przez strugę zmienia się nieznacznie w początkowej fazie wtrysku. Podczas dalszego rozpylenia paliwa rozrzuty są stałe i wynoszą około 15\% (przy odrzuceniu dwóch skrajnych przypadków) niezależnie od czasu rozpylenia paliwa. Z tego względu do dalszej analizy zasięgu i obszaru strugi wybrano uśrednione wartości zasięgów z siedmiu strug wtryskiwanego paliwa.

\subsection{Analiza zasięgu, obszaru i prędkości strugi paliwa}

Analizę zasięgu, obszarów oraz prędkości strug wykonano osobno dla każdego z badanych czasów wtrysku paliwa $\mathrm{B} 100\left(\mathrm{t}_{\text {inj1 }}=0.3 \mathrm{~ms}\right.$ oraz $\left.\mathrm{t}_{\text {inj2 }}=0.5 \mathrm{~ms}\right)-$ rys. 7 .

W przypadku wtrysku paliwa o ciśnieniu $50 \mathrm{MPa}$ prędkość propagacji frontu strugi oceniano na $60 \mathrm{~m} / \mathrm{s}$, maksymalna jego wartość jest osiągana po ok. 200-450 $\mu$ s od początku wtrysku. W środkowej fazie wtrysku prędkość propagacji jest większa o około $20-25 \mathrm{~m} / \mathrm{s}$ przy ciśnieniu wtrysku 80 $\mathrm{MPa}$ w stosunku do $50 \mathrm{MPa}$.

W przypadku wtrysku o ciśnieniu $\mathrm{P}_{\text {inj }}=80 \mathrm{MPa}$ prędkość propagacji strugi wynosiła około $80-85 \mathrm{~m} / \mathrm{s}$. W obu przypadkach wartości prędkości niemal pokrywają się $\mathrm{W}$ początkowych i końcowych fazach wtrysku.

Zasięg frontu strugi paliwa dla obu ciśnień wtrysku w początkowej fazie wtrysku jest podobna, a w końcowej fazie wtrysku różni się o 30\%.

Penetracja obu strug przy ciśnieniu $\mathrm{P}_{\text {inj }}=80 \mathrm{MPa} \mathrm{i}$ $\mathrm{t}_{\text {inj }}=500 \mu \mathrm{s}$ (podobnie jak przy ciśnieniu $50 \mathrm{MPa}$ ) w po-

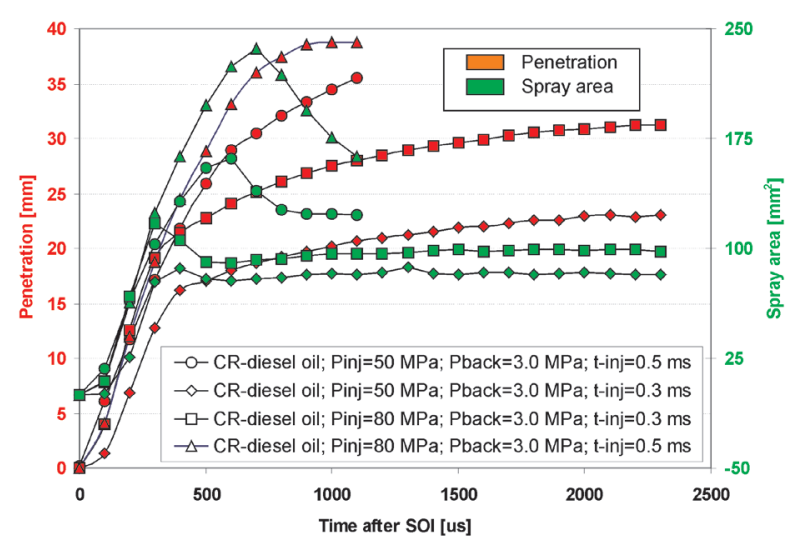

Fig. 7. The influence of the injection pressure and injection time on the fuel spray penetration and area occupied by the fuel spray

Rys. 7. Wplyw ciśnienia i czasu wtrysku na zasięg i obszar strugi paliwa 
fuel spray) to 1024 (maximum brightness). The determination of the longitudinal and transverse sections has been presented in Fig. 8.

Distance $\mathrm{x}$ (marked in Fig. 8) was selected so that in a real engine it is the distance of the actual fuel spray section that still does not come into swirl.
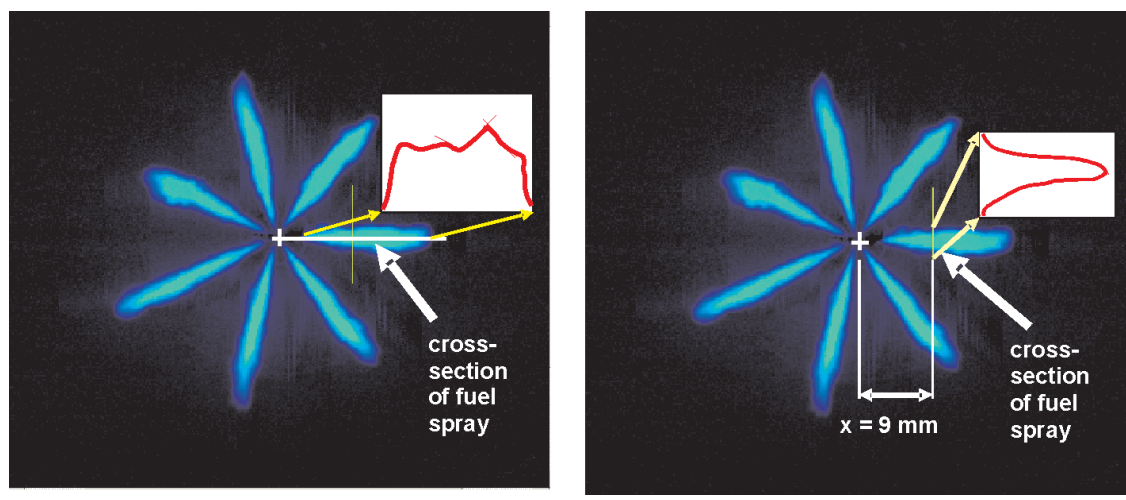

Fig. 8. Schematics of the determining of the longitudinal and transverse sections of the injected fuel spray

Rys. 8. Schemat wyznaczania przekroju wzdlużnego i poprzecznego strugi wtryskiwanego paliwa czątkowej fazie wtrysku jest identyczna, a maksymalna różnica wynosi 40\% (dla czasu od rozpoczęcia wtrysku: 1000-1200 $\mu \mathrm{s})$.

\subsection{Analiza rozkładu paliwa w osi strugi}

Rozkład paliwa w strudze oceniano w oparciu o rozkład luminancji światła odbitego od kropel paliwa w osi strugi. Wartości tej luminancji zawierają się w granicach od 0 (brak strugi paliwa) do 1024 (maksymalna jasność świecenia). Sposób wyznaczenia przekrojów wzdłużnego i poprzecznego przedstawiono na rys. 8 .

Odległość x (zaznaczona na rys. 8) dobrano w taki sposób, aby w rzeczywistym silniku była to odległość przekroju strugi, który nie ulega jeszcze zawirowaniu.

Odległość ta jest stała dla każdego pomiaru, tutaj dla czasów: $\mathrm{t}_{1}=0.5 \mathrm{~ms}$ oraz $\mathrm{t}_{2}=0.9 \mathrm{~ms}$ po rozpoczęciu wtrysku. Niewielkie przesunięcia czasowe wymuszenia wtrysku widoczne są na pierwszych zdjęciach po rozpoczęciu
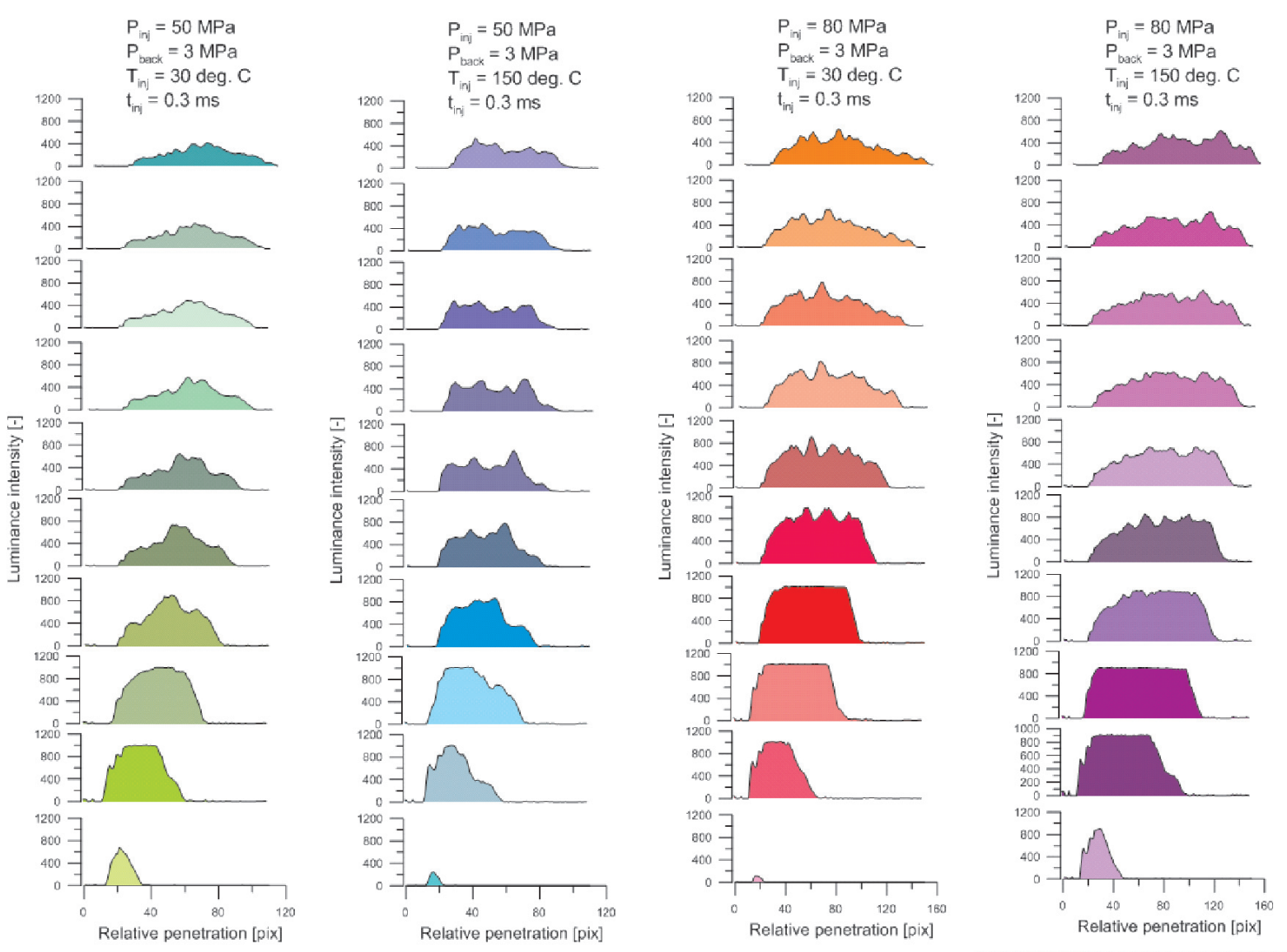

Fig. 9. Fuel distribution in the axis of the fuel spray for several values of the injection pressure and temperature of the injected fuel $\left(\mathrm{t}_{\text {inj }}=0.3 \mathrm{~ms}\right.$, first image $-0.1 \mathrm{~ms}$ after SOI, last $-1 \mathrm{~ms}$ after SOI)

Rys. 9. Rozkład paliwa w osi strugi paliwa dla kilku wartości ciśnienia wtrysku i temperatury wtryskiwanego paliwa ( $t_{i n j}=0.3$ ms, pierwsze zdjęcie $0.1 \mathrm{~ms}$ po rozpoczęciu wtrysku, ostatnie - $1 \mathrm{~ms}$ po rozpoczęciu wtrysku) 
The distance is constant for every measurement, here for times: $\mathrm{t}_{1}=0.5 \mathrm{~ms}$ and $\mathrm{t}_{2}=0.9 \mathrm{~ms}$ after SOI.

Small time displacements of the injection are visible in the first images after the onset of the injection (Fig. 9). They result from different operation of the injection actuators. They however do not significantly influence the evaluation of the fuel distribution in the fuel spray.

The lack of fuel heating causes the maximum illumination intensity (largest droplets - spray core) to locate in the central part of the fuel spray (clearly visible at lower injection pressures and shorter injection times $\left(\mathrm{P}_{\text {inj }}=50 \mathrm{MPa}\right.$, $\mathrm{T}_{\text {inj }}=30$ deg. $\mathrm{C}, \mathrm{t}_{\text {inj }}=0.3 \mathrm{~ms}$ ).

The analysis of the influence of the temperature on the quality of the fuel spray indicates an increased uniformity in the fuel distribution by higher fuel temperature, which is confirmed by the increase in the base of the curves marked red (Fig. 10). Bigger differences occur for shorter injection times (Fig. 10c, d) and lower injection pressures (Fig. 10a, c).

The differences occurring for two measuring times of the fuel distribution (for $\mathrm{t}=0.5$ and $\mathrm{t}=0.9 \mathrm{~ms}$ ) indicate a reduction in the intensity of the fuel spray illumination. Due to the specificity of the obtaining of the images we should conclude that the density of the fuel gets reduced (its light permeability increases) - Fig. 10 - images to the right of each point).
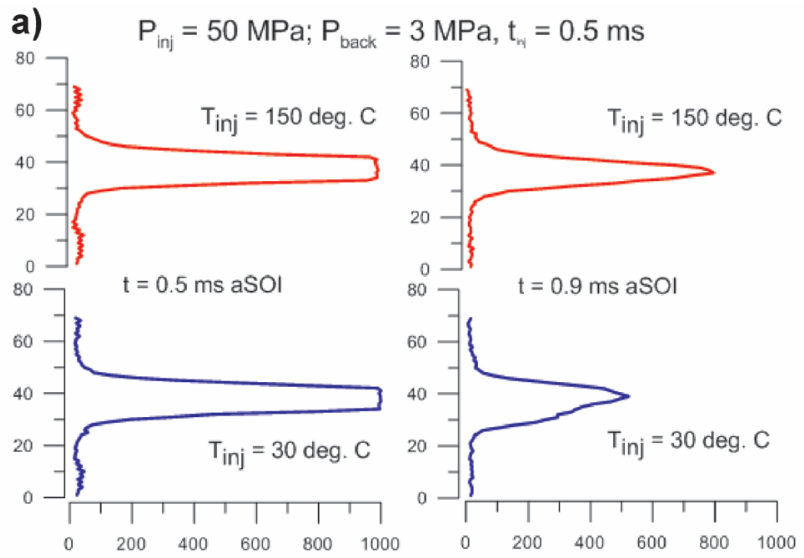

c)
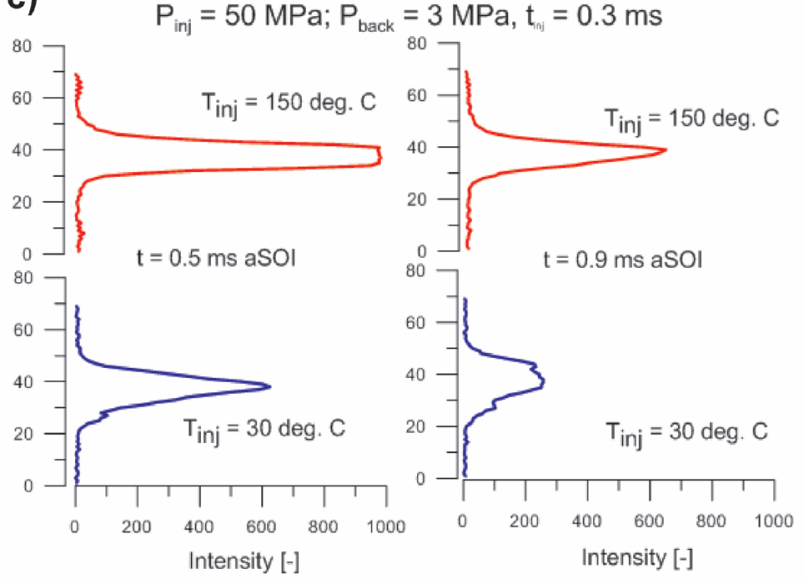

wtrysku paliwa (rys. 9). Wynikają one z niejednakowego działania układu wymuszania wtrysku. Jednak nie wpływają znacząco na ocenę rozkładu paliwa w strudze.

Brak podgrzewania paliwa powoduje, że maksymalna intensywność świecenia (największe krople - rdzeń strugi) znajduje się w środkowej części strugi paliwa (szczególnie widoczne przy mniejszych ciśnieniach wtrysku paliwa i krótszych czasach wtrysku $\left(\mathrm{P}_{\text {inj }}=50 \mathrm{MPa}, \mathrm{T}_{\text {inj }}=30^{\circ} \mathrm{C}\right.$, $\mathrm{t}_{\mathrm{inj}}=0.3 \mathrm{~ms}$ ).

Analiza wpływu temperatury na profil rozkładu paliwa w osi strugi wskazuje na zwiększenie równomierności rozkładu paliwa przy wyższej temperaturze paliwa, o czym świadczy zwiększenie szerokości podstawy krzywych oznaczonych kolorem czerwonym (rys. 10). Większe różnice występują dla krótszych czasów wtrysku paliwa (rys. 10, d) oraz niższych wartości ciśnień wtrysku (rys. 10, c).

Różnice występujące dla dwóch czasów pomiaru rozkładu paliwa ( dla $_{1}=0.5$ oraz $\mathrm{t}_{2}=0.9 \mathrm{~ms}$ ) wskazują na zmniejszenie intensywności świecenia strugi paliwa. Ze względu na sposób uzyskiwania materiału zdjęciowego, należy wnioskować, że zmniejszeniu ulega gęstość strumienia paliwa (zwiększa się jego przepuszczalność światła) - rys. 10 - rysunki z prawej strony każdego podpunktu).
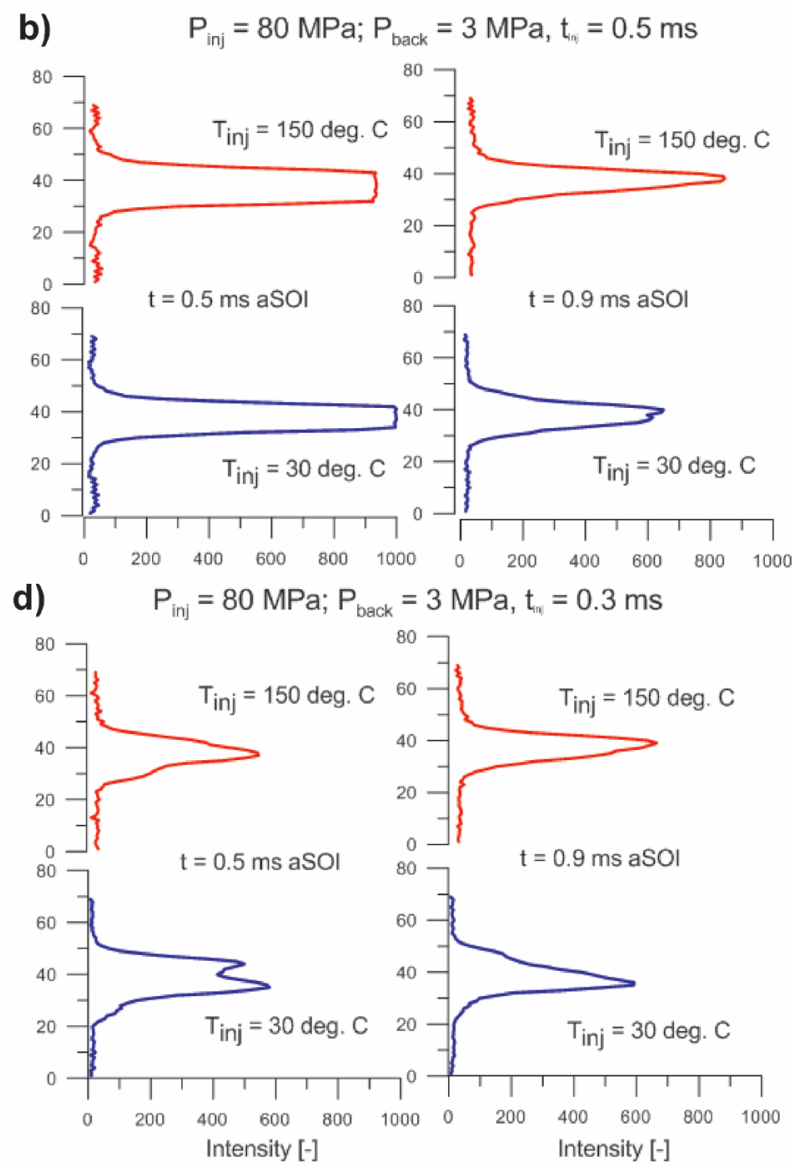

Fig. 10. Fuel distribution in a section perpendicular to the fuel spray axis at a distance of $\mathrm{x}=9 \mathrm{~mm}$ from the injector axis for two different durations starting from the SOI and for fuel temperatures 30 and 150 deg. C

Rys. 10. Rozkład strugi paliwa w przekroju prostopadtym do osi strugi w odległości $x=9$ mm od osi wtryskiwacza dla dwóch czasów od początku wtrysku i dla temperatury paliwa 30 i $150{ }^{\circ} \mathrm{C}$ 


\section{Gasoline Spray Atomization in high pressure injection system}

\subsection{Introduction}

In order to select appropriate injectors for the combustion system, it is necessary to know the characteristics of the fuel injection and the relations between the basic geometrical parameters of the spray and the basic parameters of the injection nozzle as well as the basic control values of such parameters as injection pressure, back-pressure in the research chamber and the injection duration. The research served for determination of the relations for a typical penetration of operation of a piezoelectric, high pressure gasoline injector.

The most significant injection indexes include the axial and radial penetration of the spray, the area of the spray cone, velocity of the spray distribution and evenness of the spray penetration.

The investigations into the fuel injection and its atomization were carried out for typical spark ignition cylinder pressures. The injection pressures were adapted to the contemporary piezoelectric injector design.

Current research on gasoline atomization focuses on high pressure single $[5,16]$ and multi hole $[2,10]$ injectors. The said investigations do not concentrate on the issue of gasoline 'post injection'. In the investigations with the use of outward-opening injectors $[4,9,12,18]$ the phenomenon of 'post injection' has not been investigated either.

\subsection{Linear spray penetration}

The quality of the fuel injection has been conventionally estimated taking into consideration the area occupied by the spray on its planar exposure in consecutive pictures from the recorded movies and, additionally, the profile of fuel spray penetration. This profile specifies the dispersion of spray penetration along cone generating lines on circumference of the spray cone which were determined on the spray planar exposure.

The results are plotted against the distance from the injector axle (Fig. 11a) for the time $t_{1}=300 \mu$ s after SOI (start of injection) (injection duration $\mathrm{t}=600 \mu \mathrm{s}$ ). The dotted lines denote the average value of spray penetration obtained in the manner mentioned above.

Fig. 11a shows examples of fuel spray penetration profiles (for fuel injection pressure of $\mathrm{P}_{\text {inj }}=20 \mathrm{MPa}$ ) for two different air back-pressure values.

A great diversity of spray profile of the injected fuel is visible. The growth of air back-pressure value is accompanied by a decrease in the changes in the spray profile (deviations are lesser than the medium value).

For the growth of back-pressure from 0.5 to $1.0 \mathrm{MPa}$ the width of the spray decreased by $25 \%$ (from 16.8 to 12.5 $\mathrm{mm})$.

Similar changes affected the area occupied by the fuel spray. It was determined as a projection onto the flat surface. Assuming the area occupied by the fuel spray as a reference point for the back-pressure equaling $0.5 \mathrm{MPa}$, it was confirmed that the area decreased by $25 \%$ and the back-pressure increased to $1.0 \mathrm{MPa}$ (Fig. 11b). The maximum changes of

\section{Rozpylenie paliwa w wysokociśnieniowym układzie wtrysku benzyny}

\subsection{Wprowadzenie}

Dla prawidłowego doboru wtryskiwaczy do systemu spalania niezbędna jest znajomość charakterystyki wtrysku paliwa oraz zależności podstawowych wskaźników geometrycznych strugi paliwa od parametrów geometrycznych rozpylacza i od podstawowych wielkości kontrolnych: ciśnienia wtrysku, przeciwciśnienia w komorze roboczej i czasu trwania wtrysku. Podjęte badania posłużyły do wyznaczenia tych zależności $\mathrm{w}$ typowym zakresie pracy piezoelektrycznego, wysokociśnieniowego wtryskiwacza benzyny.

Najważniejsze parametry wtryskiwanego paliwa obejmują osiową i promieniową penetrację strugi, powierzchnię stożka zajmowanego przez strugę, prędkość i równomierność rozprzestrzeniania się strugi paliwa.

Badania procesu wtrysku paliwa i jego atomizacji przeprowadzono dla typowych ciśnień występujących w silnikach o zapłonie iskrowym. Ciśnienia wtrysku były dostosowane do współczesnych konstrukcji wtryskiwaczy piezoelektrycznych.

Obecne badania rozpylenia benzyny dotyczą wysokociśnieniowych wtryskiwaczy jednootworkowych $[5,16]$ oraz wielootworowych $[2,10]$. Nie wspomina się w nich o zjawisku dotrysku benzyny. Podczas badań prowadzonych z wykorzystaniem wtryskiwaczy typu outward-opening [4, $9,12,18]$ również nie wskazano na występowanie zjawiska dotrysku paliwa.

\subsection{Linowy zasięg strugi}

Jakość wtrysku paliwa określono na podstawie zmian obszaru zajmowanego przez strugę jako płaską ekspozycję kolejno rejestrowanych obrazów oraz zasięgu strugi pojedynczego zdjęcia. Profil ten stanowi o rozrzutach zasięgu stożka strugi paliwa (płaskiej ekspozycji).

Przedstawione wartości obrazują zasięg wtrysku od osi wtryskiwacza dla czasu $t_{1}=300 \mu$ s od początku wtrysku paliwa (czas wtrysku $\mathrm{t}_{\mathrm{inj}}=600 \mu \mathrm{s}$ ). Linią przerywaną zaznaczono zasięg średni uzyskany z wartości cząstkowych.

Na rysunku 11 a przedstawiono przykładowy profil zasięgu strugi paliwa dla dwóch różnych wartości przeciwciśnienia powietrza (dla ciśnienia paliwa $\mathrm{P}_{\mathrm{inj}}=20 \mathrm{MPa}$ ).

Widoczne jest bardzo duże zróżnicowanie liniowe zasięgu strugi wtryskiwanego paliwa. Wraz ze wzrostem przeciwciśnienia powietrza rozrzuty zasięgu od wartości średniej zmniejszają się.

Przy wzroście przeciwciśnienia z 0,5 do 1,0 MPa szerokość strugi zmniejszyła się o 25\% (z 16,8 do 12,5 mm).

Podobnym zmianom ulegał obszar zajmowany przez strugę. Wyznaczono go jako rzut na powierzchnię płaską. Obszar jaki zajmuje struga przy przeciwciśnieniu równym 0,5 MPa przyjęto za wartość odniesienia. Przy wzroście przeciwciśnienia do 1,0 MPa obszar ten ulega zmniejszeniu o $25 \%$ (rys. 11b). Maksymalne zmiany obszaru zajmowanego przez paliwo występują w końcowej fazie wtrysku (dla czasu $\mathrm{t}=2,4 \mathrm{~ms}$ od początku wtrysku) i wynoszą około $82 \%$ (przy przeciwciśnieniu $\mathrm{P}_{\text {air }}=1,0 \mathrm{MPa}$ ). 
areas occupied by the fuel spray appear in the final stage of the injection (for $\mathrm{t}=2.4 \mathrm{~ms}$ from the beginning of injection) and amount to $82 \%\left(\mathrm{P}_{\text {air }}=1.0 \mathrm{MPa}\right)$.

\subsection{Axial fuel spray penetration}

The analysis of radial distribution of the spray penetration indicates that there are considerable deviations from the average value (Fig. 12a). The growth of the back-pressure causes a decrease of the spread around the average value.

For the growth of back-pressure (0.5 to $1.0 \mathrm{MPa})$, the values of average square deviation decrease by $22 \%$ (for injection pressure of $20 \mathrm{MPa}$ ) and by $8 \%$ (for the change of back-pressure from 1.0 to $1.5 \mathrm{MPa}$ ).

The increase of the injection pressure $\left(\mathrm{P}_{\text {inj }}=25 \mathrm{MPa}\right)$ causes a slight increase of the penetration spread (the growth of square deviation values by $3 \%$ ). In this case, the growth of the back-pressure causes a decrease of the deviation by 13\% (Fig. 12b).

\subsection{The influence of fuel pressure on the quality of the end of the injection}

The tests on the fuel injection with a high resolution disclosed the occurrence of the phenomenon of uncontrolled

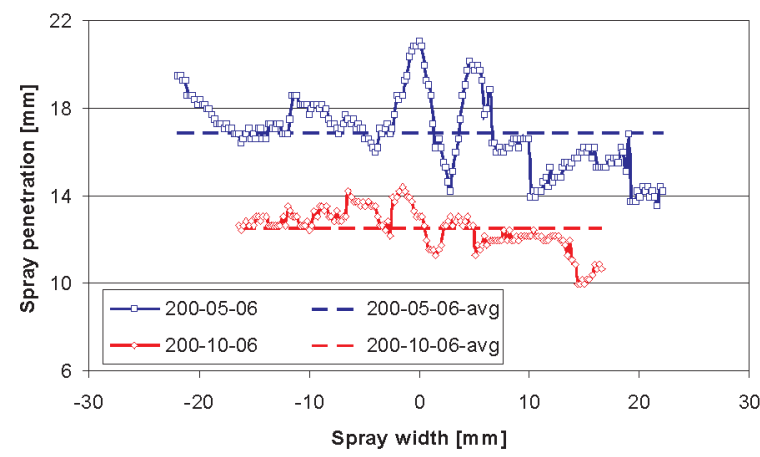

\subsection{Promieniowy zasięg strugi paliwa}

Analiza rozkładu promieniowego zasięgu strugi wskazuje na występowanie znacznych odchyleń zasięgu od wartości średniej (rys. 12a). Wzrost wartości przeciwciśnienia powoduje zmniejszenie rozrzutów wokół wartości średniej.

Przy wzroście przeciwciśnienia (od 0,5 do 1,0 MPa) wartości odchylenia kwadratowego ulegają zmniejszeniu o $22 \%$ (przy ciśnieniu wtrysku $20 \mathrm{MPa}$ ) oraz dalszym spadku tej wartości o $8 \%$ (przy zmianie przeciwciśnienia z 1,0 do $1,5 \mathrm{MPa})$.

Wzrost ciśnienia wtrysku (do $25 \mathrm{MPa}$ ) powoduje niewielkie zwiększeniu rozrzutów zasięgu (wzrost wartości odchylenia kwadratowego o 3\%). Wzrost przeciwciśnienia przy tej wartości wtrysku paliwa powoduje zmniejszenie odchylenia o $13 \%$ - rys. 12 b.

\subsection{Wpływ ciśnienia wtrysku na jakość zakończenia wtrysku}

Badania wtrysku paliwa z duża rozdzielczością ujawniły występowanie niekontrolowanego zjawiska dotrysku. Ze względu na stwierdzenie występowania nieprawidłowości

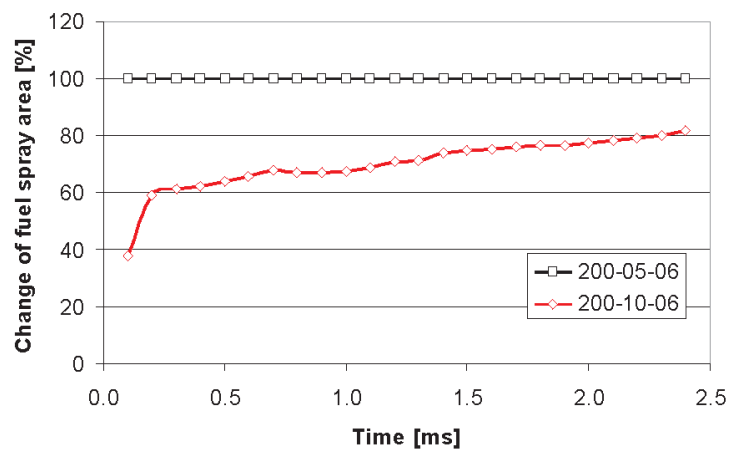

Fig. 11. Fuel spray indexes: a) profile of fuel spray penetration; b) changes of the area occupied by fuel planar exposure of the spray [\%] $\left(\mathrm{P}_{\text {inj }}=20\right.$ $\mathrm{MPa}$; back-pressure $\mathrm{P}_{\text {air }}=0.5 ; 1.0 \mathrm{MPa} ; \mathrm{t}_{1}=0.3 \mathrm{~ms} ; \mathrm{t}_{\text {inj }}=0.6 \mathrm{~ms}$ )

Rys. 11. Wskaźniki wtrysku paliwa: a) profil zasięgu strugi paliwa, b) zmiany obszaru strugi jako płaskiej ekspozycji [\%]: (P ${ }_{\text {inj }}=20$ MPa; przeciwciśnienie $P_{\text {air }}=0.5 ; 1.0 \mathrm{MPa} ; t_{1}=0.3 \mathrm{~ms} ; t_{i n j}=0.6 \mathrm{~ms}$ )
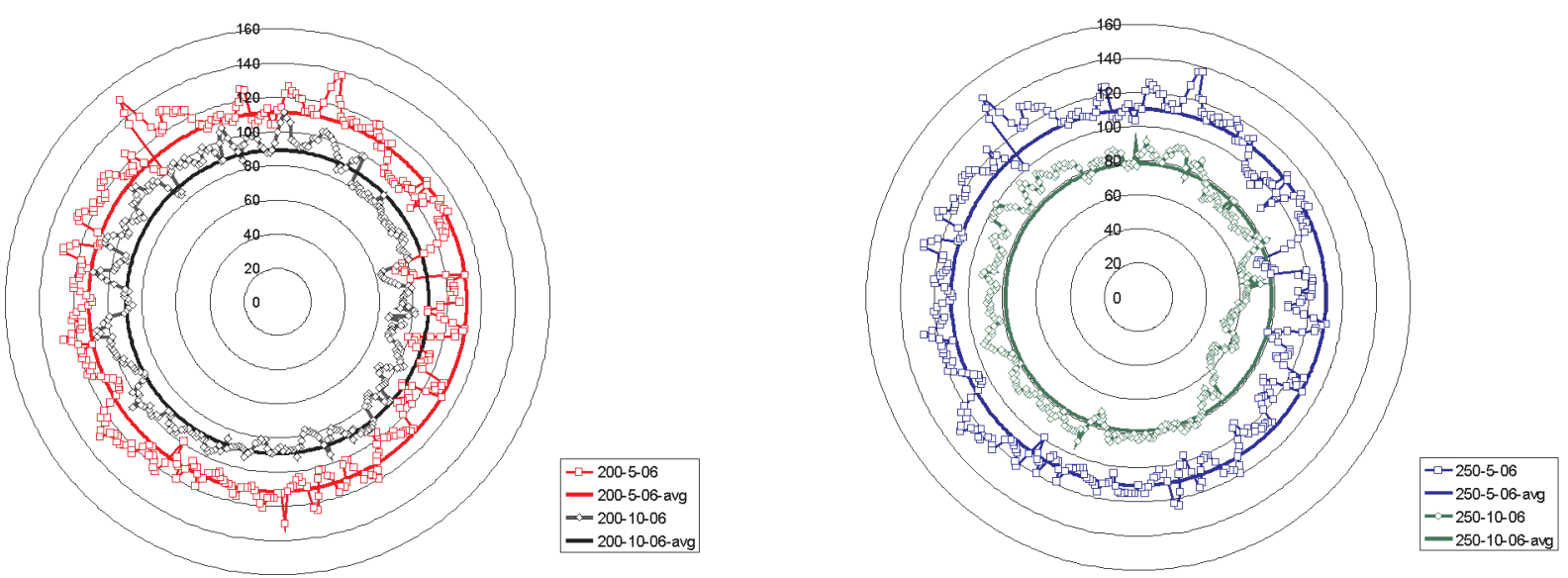

Fig. 12. Influence of back-pressure values on radial spray penetration for injection pressures: a) $\left.\mathrm{P}_{\text {inj }}=20 \mathrm{MPa} ; \mathrm{b}\right) \mathrm{P}_{\mathrm{inj}}=25 \mathrm{MPa}\left(\mathrm{t}_{1}=300 \mu \mathrm{s}\right.$; $\mathrm{t}_{\text {inj }}=600 \mu \mathrm{s}$; back-pressure $\left.\mathrm{P}_{\text {air }}=0.5 ; 1.0 \mathrm{MPa}\right)$

Rys. 12. Wplyw przeciwciśnienia powietrza na promieniowy rozkład zasięgu strugi wtryskiwanego paliwa: a) $P_{i n j}=20 \mathrm{MPa}$; b) $P_{i n j}=25 \mathrm{MPa}$ $\left(t_{1}=300 \mu \mathrm{s} ; t_{i n j}=600 \mu \mathrm{s} ;\right.$ przeciwciśnienie $\left.P_{\text {air }}=0,5 ; 1,0 \mathrm{MPa}\right)$ 
'post injection'. Due to improper realization of the final part of the injection the final fragment of the fuel outflow from the injector was analyzed. This analysis was performed with the filming frequency of $20 \mathrm{kHz}$ in the test points as shown in Table 2.

The tests were performed for a constant fuel injection time at variable backpressures. From the characteristic of the piezoelectric injectors we know that the closing speed of the injector needle depends on the differences of pressures of the fuel occurring in different parts of the injector closed with stacks of piezoelectric plates. From the above we can assume that the pressure in the accumulator system will not cause a quick closure of the injector and, at the same time an abrupt end of the injection. The results of the observations confirm the assumption and show the actual conditions of the operation of the injectors - the existence of 'post injection' of duration up to 150-200 $\mu$ s (Fig. 13). The results were obtained based on the analysis of the area of fuel outflow from the injector and determining of the brightness of the tested area.

The qualitative representation of the injector closing at different values of the fuel pressure in the accumulator (injection pressures) has been shown in Fig. 14. In order to
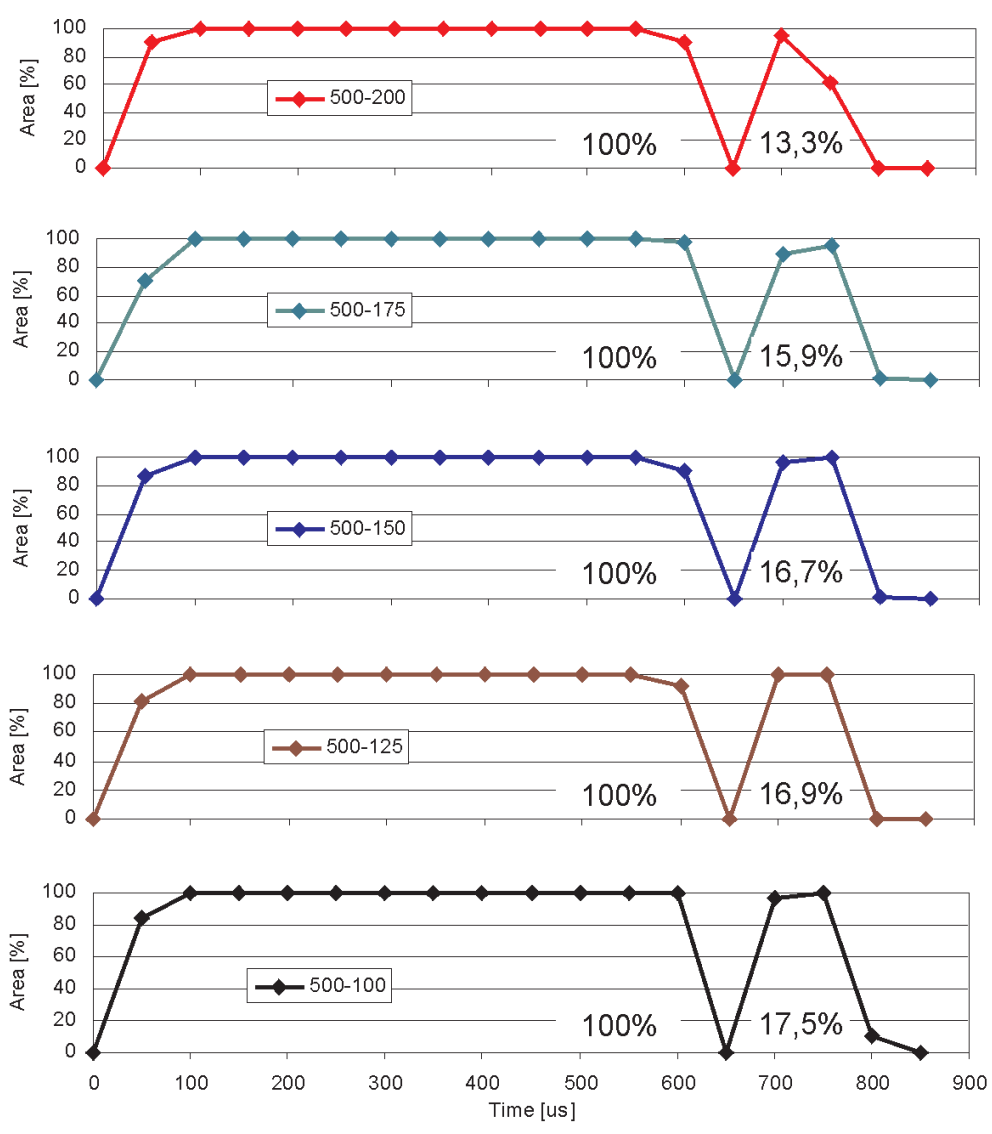

Fig. 13. The analysis of the fragment of the area of the fuel outflow from the injector: determining of the duration of the 'post injection' based on the number of pixels in a given time interval (relative values; $100 \%$ denotes the whole fuel area under analysis)

Rys. 13. Analiza fragmentu obszaru wyptywu paliwa z wtryskiwacza: określenie czasu trwania dotrysku na podstawie liczby pikseli $w$ danym przedziale czasowym (wartości względne; $100 \%$ oznacza cały analizowany obszar objęty dawka paliwa) w sposobie zakończenia wtrysku benzyny analizie poddano fragment końcowego wypływu paliwa z wtryskiwacza. Analizę tę przeprowadzono z częstotliwością filmowania $20 \mathrm{kHz}$

Table 2. The research plan of the fuel injection with a 'post injection' and the code forms used in further fuel investigations

Tablica 2. Plan badań wtrysku paliwa z dotryskiem oraz postaci kodowe wykorzystywane $w$ dalszych badaniach paliwa

\begin{tabular}{|l|c|c|c|}
\hline Lp. & $\mathrm{t}_{\mathrm{ini}}[\mathrm{us}]$ & $\mathrm{P}_{\mathrm{ini}}[\mathrm{MPa}]$ & Test code/Kod \\
\hline 1 & 500 & 10.0 & $500-100$ \\
\hline 2 & 500 & 12.5 & $500-125$ \\
\hline 3 & 500 & 15.0 & $500-150$ \\
\hline 4 & 500 & 17.5 & $500-175$ \\
\hline 6 & 500 & 20.0 & $500-200$ \\
\hline
\end{tabular}

Badania przeprowadzono dla stałego czasu wtrysku paliwa przy zmiennych wartościach przeciwciśnienia. Z charakterystyki pracy wtryskiwaczy piezoelektrycznych wiadomo, że szybkość zamykania iglicy wtryskiwacza zależy od różnicy ciśnień paliwa panujących w odpowiednich przekrojach wtryskiwacza zamykanych stosem płytek piezokwarcowych. Wynika z tego, że małe ciśnienie panujące w układzie zasobnikowym nie będzie powodowało szybkiego zamknięcia wtryskiwacza i jednocześnie gwałtownego zakończenia wtrysku. Wyniki obserwacji potwierdzają tę tezę, a jednocześnie obrazują stan faktyczny pracy wtryskiwaczy - istnienie dotrysku o czasie trwania nawet $150-200 \mu \mathrm{s}$ (rys. 13). Wyniki te uzyskano na podstawie analizy obszaru wypływu paliwa z wtryskiwacza i określeniu jasności pola objętego badaniem.

Jakościowy obraz sposobu zamykania wtryskiwacza przy różnych wartościach ciśnienia paliwa panującego w zasobniku (ciśnienia wtrysku) przedstawiono na rys. 14. Dla analizy obrazów wtrysku paliwa usunięto tło na każdym rejestrowanym zdjęciu.

W celu określenia intensywności i jakościowej oceny ilości dotryskiwanego paliwa dokonano analizy przebiegu wypływu paliwa na przedstawionych zdjęciach (rys. 14). Wyniki obrazują liczbę pikseli odpowiadających poszczególnym czasom dotrysku oraz sumaryczną liczbę pikseli odpowiadających ilości wtryśniętego paliwa (rys. 15). Zabieg taki jest konieczny ze względu na występujące niejednakowe początki dotrysku paliwa, które nie zależą od szybkości filmowania (i nie są z nią zsynchronizowane).

Z analizy wykresu wynika zależność, że wraz ze wzrostem ciśnienia wtryskiwanego paliwa (przy stałym czasie wtrysku wynoszącym $\mathrm{t}=500 \mu \mathrm{s})$ ilość dotryskiwanego paliwa zmniejsza się. Zależność ta jest zgodna z zasadą 


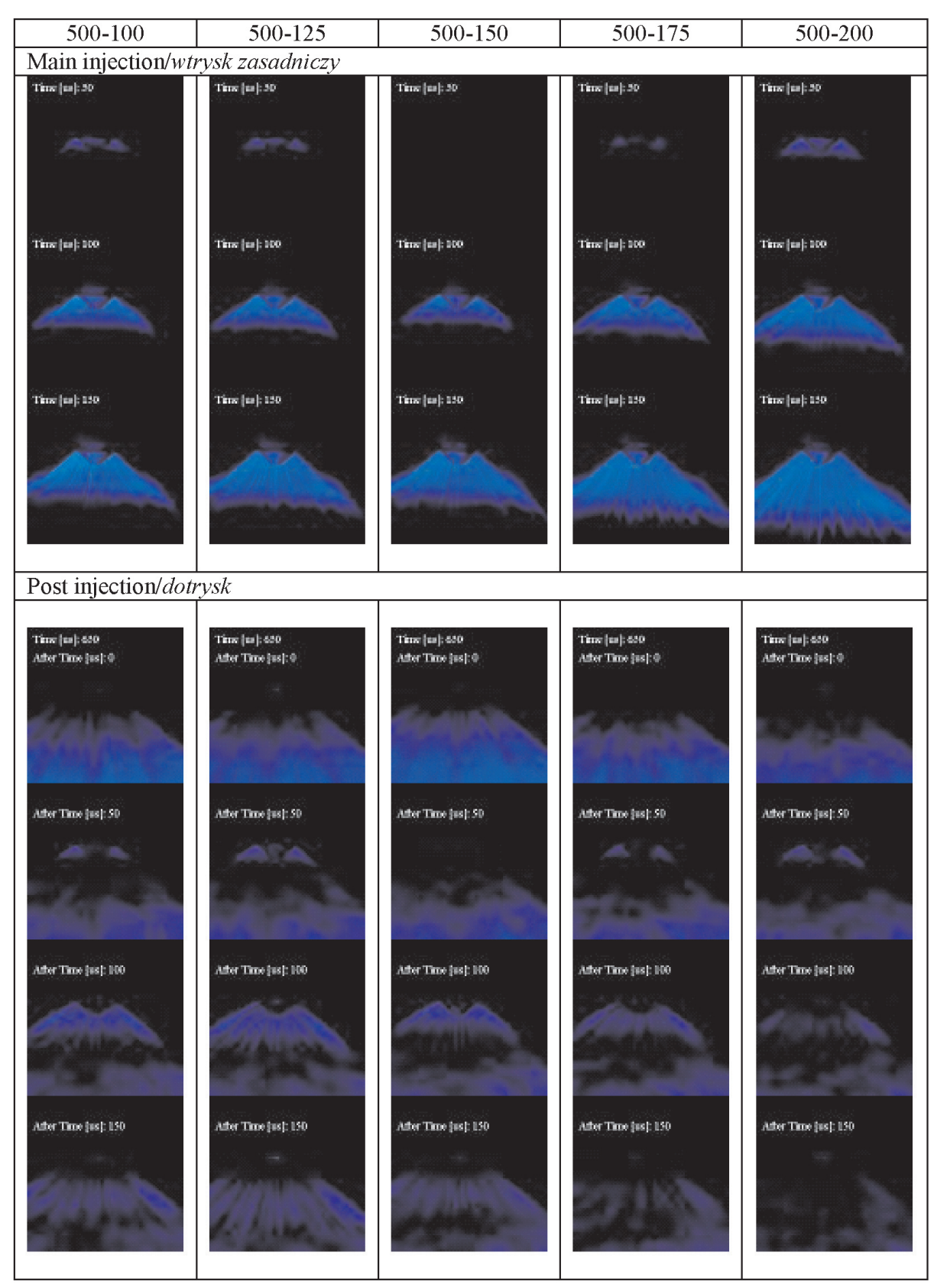

Fig. 14. The influence of the gasoline injection pressure on the qualitative result of the final phase of the injection (the occurrence of the fuel 'post injection')

Rys. 14. Wpływ wartości ciśnienia wtrysku benzyny na jakościowy obraz końcowej fazy wtrysku benzyny (występowanie dotrysku paliwa)

analyze the fuel injection images the background was erased from each presented image.

In order to determine the intensity and qualitative assessment of the 'post-injected' fuel an analysis of fuel outflow course has been carried out on the images - Fig. 14. The results show the number of pixels corresponding to the respective 'post injection' durations and the collective number of pixels corresponding to the amount of injected fuel (Fig. 15). Such an action is needed as the fuel 'post injection' onsets are not identical and are independent from the filming frequency (not synchronized with it). działania wtryskiwacza piezoelektrycznego, gdyż większe ciśnienie wtrysku powoduje szybsze zamknięcie iglicy wtryskiwacza.

Wielkość dotrysku paliwa zależny jest od wartości ciśnienia wtrysku. Zaobserwowano maksymalne dawki dotrysku dla ciśnienia paliwa $\mathrm{P}_{\text {inj }}=12,5$ MPa. Występowanie maksymalnych dotrysków może być związane $\mathrm{z}$ występowaniem częstotliwości rezonansowych dla tego typu wtryskiwaczy. Wymusza to konieczność stosowania małych (poniżej 10 $\mathrm{MPa}$ ) lub dużych (powyżej 17,5 MPa) wartości ciśnienia paliwa w układzie wtryskowym. Zakres między 10 a 17,5 MPa jest obszarem występowania znacznych dotrysków paliwa.

Analizie poddano zasięg i równomierność strugi podczas wtrysku i dotrysku paliwa przy tych samych parametrach czasowych. Wybrano zdjęcia, które odpowiadają stałym czasom $(100 \mu \mathrm{s})$ od rozpoczęcia wtrysku lub dotrysku. Przedstawiono przypadek, który powoduje znaczący dotrysk paliwa (wtrysk o parametrach $\mathrm{t}_{1}=500 \mu \mathrm{s}$ oraz wartości ciśnienia wtrysku $10 \mathrm{MPa}$ - kod 500-100). Dokonano analizy jakościowej zasięgu strug paliwa: wtrysku zasadniczego i dotrysku (rys. 16).

Średnia wartość zasięgu wzrosła o $17 \%$; zmianie uległa również szerokość strugi paliwa - wielkość ta wzrosła o $12 \%$. Wzrost zasięgu podczas dotrysku jest spowodowany wzrostem prędkości wypływu paliwa - w wyniku zmiany przekroju przepływowego - w czasie zamykania wtryskiwacza. Wyraźnemu zróżnicowaniu ulega zwartość i jednorodność strugi. Podczas wtrysku zasadniczego odchylenie średnie wynosi 2,56 . W przypadku dotrysku wielkość ta wynosi 5,65. Wynika z tego dwukrotnie większa nierównomierność zasięgu w przypadku dotrysku niż w czasie wtrysku zasadniczego. Zmniejszenie liczby pikseli określających strugę paliwa pozwala wnioskować o mniejszej wartości ciśnienia tej części dawki paliwa oraz o jej gorszym rozpyleniu. 
From the analysis of the graph results a relation that as the injected fuel pressure grows (at a constant duration of the injection $\mathrm{t}=500 \mu \mathrm{s}$ ) the amount of the 'post-injected' fuel reduces. This relation is in line with the principle of operation of piezoelectric injector as higher injection pressure results in a quicker closing of the injection needle.

The size of the fuel 'post injection' depends on the fuel injection pressure. The maximum fuel 'post injection's have been observed for the fuel pressure $\mathrm{P}_{\text {inj }}$ $=12.5 \mathrm{MPa}$. The occurrence of maximum 'post injections' may be related to the occurrence of resonant frequencies for this type of fuel injectors. This forces the application of low (below $10 \mathrm{MPa}$ ) or high (above $17.5 \mathrm{MPa}$ ) fuel injection pressures in the injection system. The range between 10 and $17.5 \mathrm{MPa}$ is the area of high 'post injection' occurrence.

The fuel spray penetration and uniformity were analyzed during the injection and 'post injection' at the same time parameters. Images were selected that correspond to constant times $(100 \mu \mathrm{s})$ from the onset of the injection or 'post injection'. A case was shown that causes a significant fuel 'post injection' (injection having the parameters $t_{1}=500 \mu$ s and the injection pressure $10 \mathrm{MPa}$ - code 500-100). A qualitative analysis was performed of the fuel spray penetration: main injection and 'post injection' (Fig. 16).

The average value of the fuel spray penetration grew by $17 \%$; the width of the fuel spray also changed - it grew by $12 \%$. The growth of the penetration during the 'post injection' is caused by the increase in the velocity of the fuel outflow - as a result of the change of the outflow diameter (when closing the injector). The fuel spray content and uniformity varies widely. During the main injection the average deviation amounts to 2.56. In the case of the 'post injection' the value is 5.65. From the above it results that in the case of 'post injection' the nonuniformity of the penetration grows twice as opposed to the main injection. The reduction of the number of pixels determining the fuel spray allows a conclusion that the pressure of this fuel dose is lower and the atomization is worse.

\section{Summary}

The main target of the research reported in this paper was to determine the injection course and its quality indexes in the piezoelectric injection systems, both for SI and CI engines, according to the injection pressure, fuel temperature and back-pressure.

According the bio-fuel (B100) injection by the multi-hole injector used in Diesel engines it was stated that:

1. The analysis of the fuel spray penetration indicates that there is a lack of uniformity in the fuel atomization by all injection holes of a piezoelectric injector. We obtain

\section{Podsumowanie}

Głównym zadaniem badań omawianych w tym artykule było określenie przebiegu procesu wtrysku i wyznaczenie jego wskaźników jakości dla wtryskiwaczy piezoelektrycznych, stosowanych zarówno w silnikach ZI jak i ZS, w zależności od ciśnienia wtrysku, temperatury paliwa i przeciwciśnienia.

W odniesieniu do wtrysku biopaliwa B100 przez wtryskiwacz wielootworkowy stosowany w silniku

ZS stwierdzono, że:
1. Analiza zasięgu strug paliwa wskazuje na istnienie rozbieżności w rozpyleniu paliwa przez wszystkie otworki wtryskiwacza piezoelektrycznego. Uzyskuje się rozrzuty o wartości od 15 do $20 \%$ w zależności od czasu rozpylenia paliwa od początku wtrysku. Podobne rezultaty uzyskuje się przy ocenie obszaru zajmowanego przez poszczególne strugi paliwa.

2. Wzrost omawianego obszaru osiąga maksymalną wartość w końcowej fazie wtrysku i wynosi około 40\%. Wartość ta jest niezależna od ciśnienia i czasu wtrysku.

3. Wraz ze wzrostem ciśnienia wtrysku następuje zwiększenie prędkość strugi. Obserwowany jest wzrost prędkości strugi podczas wypływu z wtryskiwacza. Po zakończeniu wtrysku następuje stabilizacja prędkości.

Dla przypadku bezpośredniego wtrysku benzyny przy użyciu piezoelektrycznego wtryskiwacza typu outwardopening i stożkowego ukształtowania strugi można stwierdzić, że:

1. Szczegółowa analiza rozkładu promieniowego strugi wskazuje na występowanie znacznych odchyleń zasięgu od wartości średniej. Wzrost wartości przeciwciśnienia powoduje zmniejszenie rozrzutów strugi wokół wartości średniej. Obliczone odchylenia kwadratowe wskazują na $22 \%$ spadek wartości przy wzroście przeciwciśnienia o 50\% (przy ciśnieniu wtrysku $20 \mathrm{MPa}$ ) oraz dalszym spadku tej wartości o $8 \%$ (przy zmianie przeciwciśnienia o kolejne 25\%). Zmiana ciśnienia wtrysku o $25 \%$ powoduje zwiększenie odchylenia kwadratowego o 3\%. Wzrost przeciwciśnienia przy tej wartości wtrysku paliwa powoduje zmniejszenie odchylenia o $13 \%$.

2. Wraz ze wzrostem ciśnienia wtryskiwanego paliwa ilość dotryskiwanego paliwa zmniejsza się. Przy wzroście ciśnienia paliwa o 50\% następuje spadek obszaru objętego dodatkowym wtryskiem paliwa o 5\%. Wzrost o $100 \%$ powoduje zmniejszenie tego obszaru o 25\%. Wynika stąd, że występowanie dotrysku mocno zależy od ciśnienia wtrysku paliwa. 
spreads of the values from 15 to $20 \%$ depending on the fuel atomization time counting from the onset of the injection. Similar results we obtain when evaluating the area occupied by individual fuel sprays.

2. The growth of the said area reaches a maximum value at the end of the injection and amounts to approximately $40 \%$. The value is independent of the injection pressure and injection time.

3 The fuel spray velocity increases as it injection pressure grows up. We can observe an increase in the fuel spray velocity as it flows out of the injector. After the end of the injection the velocities equalize.

For the case of gasoline direct injection using piezoelectric outward-opening injector and cone-shape spray it could be concluded that:

1. A detailed analysis of the radial spray distribution indicates significant deviations in the spray penetration from the average value. The increase in the backpressure results in the reduction of the fuel spray spreads from the average value. The calculated average squared deviations indicate a $22 \%$ drop in the value as the backpressure grows by $50 \%$ (at the injection pressure of $20 \mathrm{MPa}$ ). The change in the fuel injection pressure by $25 \%$ results in an increase in the average squared deviation by $3 \%$. The increase in the backpressure at this injection value results in the reduction of the deviation
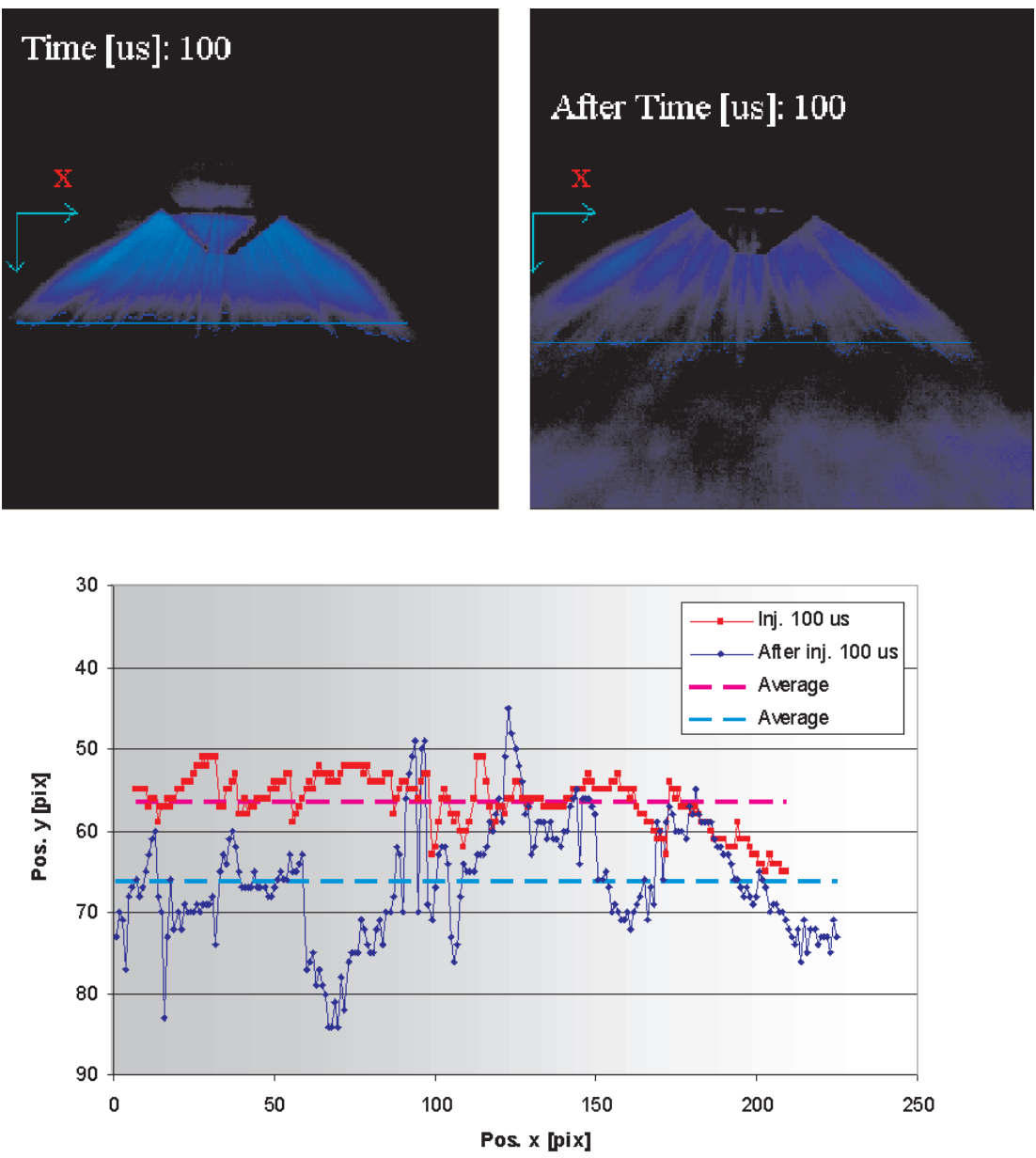

Fig. 16. The analysis of the fuel spray penetration and uniformity $100 \mu$ s from the onset of the injection and $100 \mu$ s from the 'post injection'

Rys. 16. Analiza zasięgu i równomierności strugi paliwa podczas $100 \mu$ s od początku wtrysku $i$ $100 \mu$ s od dotrysku paliwa

3. Występowanie maksymalnych dotrysków może być związane z występowaniem częstotliwości rezonansowych dla tego typu wtryskiwaczy. Wymusza to konieczność stosowania małych (poniżej $10 \mathrm{MPa}$ ) lub dużych (powyżej 17,5 MPa) wartości ciśnienia paliwa w układzie wtryskowym. Zakres między 10 a 17,5 MPa jest obszarem występowania znacznych dotrysków paliwa.

4. Analiza strugi wtrysku i dotrysku (przy tym samym czasie od początku danej dawki paliwa) wskazuje na istnienie zmian w zasięgu i szerokości strugi paliwa. Zasięg ulega zwiększeniu o $17 \%$ natomiast szerokość strugi o $12 \%$. Zaobserwowano dwukrotne zwiększenie nierównomierności zasięgu strugi określone przez odchylenie od linii średniej. of high 'post injection' occurrence.

4. The analysis of the fuel spray, fuel injection and 'post injection' (the same time from the onset of a given fuel dose) indicates changes in the fuel spray penetration and width. The spray penetration increases by $17 \%$ and the fuel spray width by $12 \%$. The non-uniformity of the spray penetration increases twice as determined by mean square deviation.

Paper reviewed/Artykut recenzowany 


\section{Acknowledgments}

This work has been sponsored by the Polish Ministry of Science an Higher Education as a research project No NN 502088438 in the years 2010-2012.

\section{Źródlo finansowania}

Prezentowana praca została wykonana $\mathrm{w}$ ramach projektu badawczego nr NN 502088438 finansowanego przez Ministerstwo Nauki i Szkolnictwa Wyższego w latach 2010-2012.

\section{Bibliography/Literatura}

[1] 2009 Annual Book of ASTM Standards, Vol. 05.04, ASTM International, 100 Barr harbor Drive, PO Box C700, West Conshohocken, PA, 19428, www.astm.org.

[2] Bianchi G.M., Negro S., Forte C., Cazzoli G., Pelloni P., The Prediction of Flash Atomization in GDI Multi-Hole Injectors, SAE 2009-01-1501, 2009.

[3] Biodiesel Standards EN 14214.

[4] Bock Ch., Hirschfelder K., Ofner B., Schwarz Ch.: Motortechnische Zeitschrift 12:42-49, vol. 69 (2008).

[5] Choi D.-S., Bae Ch., Kim D.-J., Proc. Instn Mech. Engrs 218:745-754 (2004).

[6] Geng P.Y., Buczynsky A.E., Konzack A.: US and EU Market Biodiesel Blends Quality Review - An OEM Perspective, SAE Technical Paper 2009-01-1850 (2009).

[7] Guido C., Beatrice C., Di Iorio S., Fraioli V., Di Blasio G., Alternative Diesel Fuels Effects on Combustion and Emissions of an Euro5 Automotive Diesel Engine, SAE Technical Paper 2010-01-0472, 2010.

[8] Horn U., Persson H., Egnell R., Andersson Ö., Rijk E., The Influence of Fuel Properties on Transient Liquid-Phase Spray Geometry and on CI-Combustion Characteristics, SAE 200901-2774, 2009.

[9] Kim S.-J., Kim Y.-N., Lee J.-H.: Analysis of the In-Cylinder Flow, Mixture Formation and Combustion Processes in a Spray-Guided GDI Engine, SAE Technical Paper 2008-010142, 2008.

[10] Mitroglou N., Nouri J.M., Yan Y., Gavaises M., Arcoumanis C., :Spray Structure Generated by Multi-Hole Injectors for Gasoline Direct-Injection Engines, SAE 2007-01-1417, 2007.

[11] Northrop W.F., Bohac S.V., Assanis D.N., Premixed Low Temperature Combustion of Biodiesel and Blends in a High
Speed Compression Ignition Engine, SAE Technical Paper 2009-01-0133, 2009.

[12] Schwarz C., Schünemann E., Durst B., Fischer J., Witt A.: Potentials of the Spray-Guided BMW DI Combustion System, SAE Technical Paper 2008-01-1265, 2008.

[13] Senda J., Ikeda T., Haibara T., Sakurai S., Wada Y., Fujimoto H., Spray and Combustion Characteristics of Reformulate Biodiesel with Mixing of Lower Boiling Point Fuel, SAE 2007-01-0621, 2007.

[14] Senda J., Okui N., Suzuki T., Fujimoto H.: Flame Structure and Combustion Characteristics in Diesel Combustion Fueled with Bio-diesel, SAE Technical Paper 2004-01-0084, 2004.

[15] Szybist J.P., Boehman A.L.: Behavior of a Diesel Injection System with Biodiesel Fuel, SAE Technical Paper 2003-011039, 2003.

[16] Wang Y.-J., Wang J.-X., Shuai S.-J., Lei X.-H., An, X.-L.: Study of Injection Strategies of Two-stage Gasoline Direct Injection (TSGDI) Combustion System, SAE 2005-01-0107, 2005.

[17] Wislocki K., Pielecha I., Czajka J.: A comparative analysis of diesel fuel injection parameters in piezoelectric and electromagnetic fuel injectors, Combustion Engines 3(138), pp. 54-63, 2009.

[18] Wislocki, K., Pielecha, I., Czajka, J., Maslennikov, D.: The Influence of Fuel Injection Parameters on the Indexes of Fuel Atomization Quality for a High Pressure Injection, SAE 201001-1499, 2010.

[19] Xusheng Z., Haibin W., Liguang L., Zhijun W., Zongjie H., Hui Z.: Characteristics of Output Performances and Emissions of Diesel Engine Employed Common Rail Fueled with Biodiesel Blends from Wasted Cooking Oil, SAE Technical Paper 200801-1833, 2008.
Prof. Krzysztof Wisłocki, DSc, DEng. - Professor at the Faculty of Working Machines and Transportation of Poznan University of Technology.

Prof. nzw. dr hab. inż. Krzysztof Wisłocki-Profesor nzw. na Wydziale Maszyn Roboczych i Transportu Politechniki Poznańskiej.

e-mail: krzysztof.wislocki@put.poznan.pl

Mr. Dmitrij Maslennikov, MEng. - post-graduated student at the Faculty of Working Machines and Transportation of Poznan University of Technology.

Mgr inż. Dmitrij Maslennikov - doktorant na Wydziale Maszyn Roboczych i Transportu Politechniki Poznańskiej.

e-mail:dmytro.maslennikov@put.poznan.pl
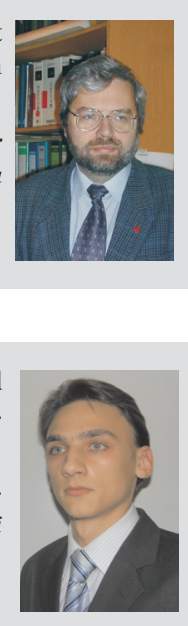

Mr. Ireneusz Pielecha, DEng. - doctor at the Faculty of Working Machines and Transportation of Poznan University of Technology.

Dr inż. Ireneusz Pielecha - adiunkt na Wydziale Maszyn Roboczych i Transportu Politechniki Poznańskiej. e-mail: ireneusz.pielecha@put.poznan.pl

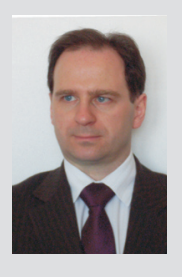

Mr. Jakub Czajka, DEng. - doctor at the Faculty of Machines and Transportation of Poznan University of Technology.

Dr inż. Jakub Czajka - adiunkt na Wydziale Maszyn Roboczych i Transportu Politechniki Poznańskiej. e-mail: jakub.czajka@put.poznan.pl 